\title{
RANCANG BANGUN DAN UJI KINERJA MESIN PENYARING SISTEM GETAR UNTUK MEMISAHKAN BIJI DAN KULIT HANJELI HASIL PROSES PENGUPASAN
}

\section{DESIGN AND PERFORMANCE EVALUATION OF VIBRATING SIEVE TO SEPARATE HANJELI SEEDS AND SKIN}

\author{
Asep Yusuf ${ }^{1} \bowtie$, Wahyu Sugandi ${ }^{1}$, Desi Purnamasari ${ }^{1}$ \\ ${ }^{1}$ Departemen Teknik Pertanian dan Biosistem, Universitas Padjadjaran \\ \omunikasi Penulis, email: asep.yusuf@unpad.ac.id \\ DOI:http://dx.doi.org/10.23960/jtep-l.v10i1.1-9 \\ Naskah ini diterima pada 26 Mei 2020; revisi pada 9 September 2020; \\ disetujui untuk dipublikasikan pada 20 November 2020
}

\begin{abstract}
Hanjeli (Coixlacryma-jobiL.) is a cereal plant which has potential in producing carbohydrate. The high nutrient content of this plant has not been utilized optimally. In Indonesia, most of the hanjeli seed peeling processes are still using the manual way (pounding), so after the peeling process we have to do seeds and peel separating process. The purpose of this research is to devise a seed and peel filter machine occupied the results of the peeling process with vibrating screen which have been adjusted for the characteristic of hanjeli seeds. The method used in this research is engineering process, which is an activity to devise a hanjeli filter machine. The result of this research was the machine which has been designed with hopper, framework, filter unit, activator, seeds outlet, husk outlet and crank shaft as the main components. The main dimensions of the machine were $1340 \mathrm{~mm}$ long, $610 \mathrm{~mm}$ wide, $1000 \mathrm{~mm}$ high, the machine's actual capacity was $29.024 \mathrm{~kg} / \mathrm{h}$ and the activator is $0.5 \mathrm{HP}$. The results of the hanjeli filter engine test are: the actual engine capacity is $29.024 \mathrm{~kg} / \mathrm{hour}$, the engine efficiency is $38.7 \%$, the pulley rotation speed is $305 \mathrm{rpm}$, the electric motor power is $0.138 \mathrm{~kW}$, and the noise level is $62.78 \mathrm{~dB}$.
\end{abstract}

Keywords: designing, hanjeli seed, hanjeli peel, performance test, vibrating screen

\begin{abstract}
ABSTRAK
Hanjeli (Coix lacryma-jobi L.) merupakan tanaman serealia yang berpotensi sebagai penghasil karbohidrat. Kandungan nutrisi hanjeli yang cukup tinggi saat ini masih belum dapat dimanfaatkan secara optimal. Di Indonesia proses pengupasan kulit biji hanjeli mayoritas masih menggunakan cara manual (ditumbuk), sehingga setelah proses pengupasan perlu dilakukan proses pemisahan biji dan kulit hanjeli. Tujuan dari penelitian ini yaitu merancang bangun mesin penyaring biji dan kulit hanjeli hasil proses pengupasan dengan menggunakan prinsip getar (vibrating screen) yang disesuaikan dengan karakteristik fisik biji hanjeli. Metode yang digunakan pada penelitian ini yaitu metode rekayasa (engineering), yaitu kegiatan merancang mesin penyaring hanjeli.Mesin penyaring hanjeli telah berhasil dirancang bangun dengan komponen utama terdiri dari: hopper, rangka, unit penyaring, motor penggerak, saluran pengeluaran kulit, saluran pengeluaran biji, saluran pengeluran dedak dan poros engkol. Dimensi utama mesin yaitu: panjang $1340 \mathrm{~mm}$, lebar $610 \mathrm{~mm}$, tinggi $1000 \mathrm{~mm}$. Hasil pengujian mesin penyaring hanjeli yaitu: kapasitas aktual mesin yaitu $29,024 \mathrm{~kg} / \mathrm{jam}$, efiesiensi mesin 38,7 \%, kecepatan putaran puli $305 \mathrm{rpm}$, daya motor listrik 0,138 kW, dan tingkat kebisingan $62,78 \mathrm{~dB}$.
\end{abstract}

Kata Kunci: biji hanjeli, kulit hanjeli, rancang bangun, uji kinerja, vibrating screen

\section{PENDAHULUAN}

Ketersediaan sumber pangan menjadi salah satu masalah utama di dunia, khususnya di negara berkembang termasuk Indonesia. Disisi lain, produksi beras dalam negeri masih belum mampu memenuhi kebutuhan penduduk Indonesia yang setiap tahunnya terus 
meningkat. Berdasarkan data Badan Pusat Statistik pada tahun 2016, jumlah pendudukIndonesia meningkat sebesar 1,49\% dari tahun sebelumnya sedangkan produksi beras hanya meningkat $1,24 \%$. Konsumsi beras di Indonesia mencapai 135,20 kg/kapita/tahun jauh melebihi rata-rata tingkat konsumsi dunia yaitu $60 \mathrm{~kg} / \mathrm{kapita} /$ tahun (Badan Pusat Statistik, 2016). Salah satu upaya mengatasi masalah ketergantungan beras tersebut adalah dengan pengembangan pangan lokal. Indonesia memiliki beragam tanaman penghasil sumber karbohidrat alternatif non beras yang berpotensi untuk pengembangan diversifikasi pangan lokal (Nurmala dkk., 2009).

Tanaman serealia lokal yang potensial sebagai penghasil karbohidrat salah satunya adalah tanaman hanjeli (Coixlacryma-jobi L.). Biji hanjeli dapat digunakan sebagai bahan pangan, sebagai sumber karbohidrat dengan nilai gizi cukup memadai sekitar 76,40\% karbohidrat, $7,90 \%$ lemak dan $14,10 \%$ protein (Nurmala dan Irwan, 2007). Hanjeli merupakan salah satu serealia sumber karbohidrat di Indonesia dan beberapa kawasan seperti China bagian selatan (Duke, 1983). Hasil percobaan yang dilakukan Yulianto dkk (2006), hanjeli mengandung protein, lemak, vitamin B1 yang lebih tinggi dibandingkan serealia lainnya, kadar kalsium lebih tinggi dibandingkan beras, jagung dan sorgum. Akan tetapi, untuk mengolah biji hanjeli melewati beberapa tahapan seperti perontokan, pengeringan, pengupasan, penyosohan, sampai bahan siap diolah menjadiolahan pangan. Kandungan nutrisi hanjeli yang cukup tinggi saat ini masih belum dapat dimanfaatkan secara optimal. Hal ini dikarenakan pengembangan hanjeli itu sendiri, pemanfaatan hanjeli oleh petani masih terkendala dengan fasilitas yang diperlukan seperti mesin pengupas biji dan peralatan pengolahan pascapanen lainnya.

Di Indonesia sendiri proses pengupasan kulit biji hanjeli mayoritas masih menggunakan cara manual (ditumbuk), hasilnya kurang efektif dan waktu pengerjaan membutuhkan waktu yang lama. Tenaga manusia hanya mampu menghasilkan kapasitas pengupasan sebanyak 1,33 kg/jam (Taufan, 2014).
Laboratorium Alat dan Mesin Pertanian, telah merancang bangun mesin pengupas hanjeli (MPH-TEP 0218) dengan menggunakan prinsip gesekan silinder dengan pengarah yang akan memecah kulit, akan tetapi hasil pengujian menunjukan bahwa pada output yang dihasilkan mesin pengupas ini masih belum baik karena biji dan kulit hanjeli hasil pengupasan masih bercampur, sehingga diperlukan mesin untuk memisahkan bagianbagian tersebut. Tujuan penelitian ini adalah merancang bangun mesin penyaring dengan sistem getar (vibrating screen) untuk memisahkan biji dan kulit hanjeli hasil proses pengupasan dan melakukan pengujian terhadap mesin yang telah dirancang.

\section{BAHAN DAN METODE}

Penelitian ini dilaksanakan pada bulan Juli sampai dengan Oktober 2018 bertempat di Laboratorium Alat dan Mesin Pertanian, Fakultas Teknologi Industri Pertanian, Universitas Padjadjaran, Jatinangor.

Bahan yang digunakan dalam penelitian terbagi dua yaitu bahan untuk pembuatan mesin dan biji hanjeli untuk pengujian. Pada tahap rancang bangun, peralatan yang digunakan adalah mesin las, alatpotong plat, gerinda potong, dan lain-lain. Pada tahap pengujian mesin peralatan yang digunakan yaitu: tachometer, soundlevel meter, vibration meter, dan clampon meter.

\subsection{Tahapan Penelitian}

Berdasarkan tahapan penelitian pada Gambar 1, maka dapat dijelaskan pelaksanaan penelitian sebagai berikut:

\section{1) Identifikasi Masalah}

Pada tahap ini dilakukan pengumpulan datadata yang mendukung kegiatan penelitian. Datadata tersebut didapatkan melalui kajian studi literatur, pengamatan di lapangan maupun hasil uji kinerja mesin yang telah dilakukan untuk mendukung kegiatan penelitian mengenai unit penyaring mesin pengupas hanjeli. Masalah utama pada mesin pengupas hanjeli MPH TEP0218 adalah output yang dihasilkan masih berupa campuran biji, kulit dan lapisan epicarp. 


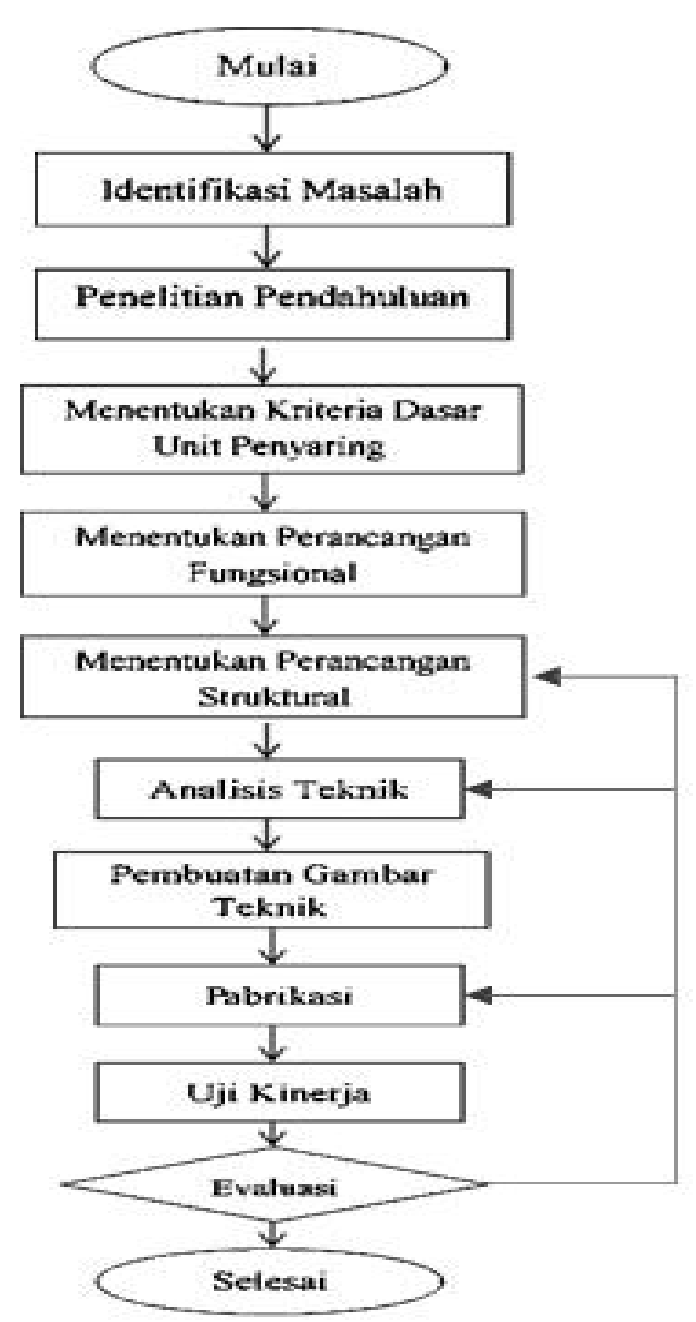

Gambar1. Tahapan Penelitian

\section{2) Penelitian Pendahuluan}

Penelitian pendahuluan dilakukan untuk mengetahui faktor yang mempengaruhi pada proses penyaringan hanjeli, yaitu dengan menentukan jenis saringan yang tepat untuk memisahkan hanjelidan dengan melakukan pengujian karakteristik biji hanjeli seperti kebulatan, sudut repos dan kekerasan.

\section{3) Penentuan Kriteria Perancangan}

Tahapan ini dilakukan untuk menentukan kriteria perancangan unit penyaring biji hanjeli dan kulit hanjeli sebagai dasar perancangan. Adapun kriteria untuk perancangan yang telah dilakukan serta penelitian sebelumnya pada perancangan mesin pengupas hanjeli $\mathrm{MPH}$ TEP0218.

\section{4) Perancangan}

Terdapat 3 hal yang harus diperhatikan saat melakukan perancangan mesin, yaitu: a. Perancangan Fungsional

Rancangan fungsional dilakukan untuk menentukan fungsi unit penyaring biji dan kulit hanjeli dan menentukan fungsi mesin secara keseluruhan.

b. Perancangan Struktural

Rancangan struktural dilakukan untuk menentukan bentuk, tata letak dan ukuran setiap bagian unit penyaring.

c. Analisis Teknik

Analisis teknik dilakukan untuk mengetahui keterkaitan hubungan antar komponen penyusun mesin dan mekanisme mesin. Analisis teknik bertujuan untuk menganalisis mekanisme mesin agar dapat bekerja dengan baik yaitu dapat memisahkan biji hanjeli dengan baik dan memenuhi spesifikasi yang diinginkan.

\section{5) Pembuatan Gambar Teknik}

Pembuatan gambar mengacu pada hasil analisa rancangan fungsional, rancangan struktural,dan 
hitunganan alisis teknik. Proses penggambaran ini bertujuan untuk membuat rancangan secara visual sehingga akan mempermudah dalam proses pembuatan mesin pengupas hanjeli dengan menggunakan software AutoCAD.

\section{6) Pembuatan Mesin Penyaring}

Pembuatan mesin penyaring pada mesin pengupas hanjeli MPHTEP-0218 dilakukan berdasarkan pada hasil tahapan perancangan fungsional dan perancangan struktural yang telah dilakukan sebelumnya. Pembuatan unit penyaring ini berdasarkan pada kesesuaian terhadap gambar teknik yang telah dibuat sebelumnya.

\section{7) Pengujian Mesin}

Pada tahapan uji kinerja dilakukan untuk melihat sejauh mana seluruh komponen berfungsi dengan baik seperti yang diharapkan dan juga untuk melihat kapasitas serta kinerja unit penyaring. Tujuan dari pengujian ini adalah untuk mengetahui karakteristik teknik unit penyaring hanjeli meliputi: kapasitas aktual, rendemen, efesiensi kinerja mesin, kebutuhan daya, analisis hasil, kebisingan dan getaran yang ditimbulkan pada saat mesin bekerja.

\section{8) Evaluasi}

Evaluasi dilakukan setelah mesin diuji coba. Apabila hasil pengujian sesuai dengan kriteria, maka mesin tersebut sudah baik. Tetapi, apabila belum sesuai akan dievaluasi proses rancangan struktural, analisis teknik maupun proses pembuatannya. Setelah diperoleh penyebab ketidaksesuaian, langkah berikutnya dilakukan modifikasi. Hasil modifikasi kemudian mesin diuji coba kembali.

\section{HASIL DAN PEMBAHASAN}

\subsection{Kriteria Mesin}

Perancangan bertujuan untuk membuat suatu produk desain guna memenuhi kebutuhan masyarakat. Adapun kriteria perancangan mesin yang dirancang diharapkan dapat memenuhi kriterias ebagai berikut: 1) Kapasitas teoritis mesin $75 \mathrm{~kg} / \mathrm{jam}$, 2) Kriteria teknis (operator 1 orang, mudah dioperasikan dan aman bagi operator, sumber daya berasal dari motor listrik dengan daya 0,5 HP), 3) Dapat memisahkan biji dengan kulit hanjeli hasil proses pengupasan (lapisan pericarp dan mesocarp), 4) Biji hanjeli dapat tersalurkan melalui corong pengeluaran, dan 5) Sistem penyaringan menggunakan sistem poros engkol.

\subsection{Rancangan Fungsional}

Output dari mesin penyaring hanjeli adalah biji hanjeli yang sudah terkupas dapat terpisahkan menjadi tiga fraksi yaitu kulit, biji, dan lapisan epicarp, untuk memenuhi fungsi utama maka diperlukan fungsi penunjang yaitu saringan, poros engkol dengan mempertimbangkan aspek ergonomi dan antropometri. Untuk memperoleh hasil tersebut, maka diperlukan beberapa bagian alat dengan fungsi yang spesifik disajikan pada Gambar 2.

\subsection{Pembuatan Gambar Mesin}

Pembuatan gambar mesin didasarkan pada kriteria rancangan, Tahapan ini ditentukan dengan bentuk dan tataletak dari setiap komponen mesin yang digunakan baik secara fungsional dan struktural. Berikut merupakan desain struktural keseluruhan yang disajikan pada Gambar 3a.

\subsection{Mesin Hasil Rancang Bangun}

Mesin penyaring hanjeli ini dibuat dengan fungsi dan struktur sesuai perancangan (Gambar 3b), akan tetapi ada penambahan komponen yaitu penambahan roda dengan bahan fiber disamping unit penyaring untuk meminimalisir terjadinya gesekan yang terjadi pada unit penyaring dan rangka yang akan menimbulkan kebisingan dan getaran yang akan mengganggu bagi operator. Pada perancangan awal saringan yang dibutuhkan untuk saringan pertama adalah $6 \mathrm{~mm}$, akan tetapi karena tidak tersedianya saringan dengan ukuran $6 \mathrm{~mm}$ dipasaran maka menggunakan saringan elips dengan diameter $7 \mathrm{~mm}$, sehingga pada proses pabrikasi untuk saringan pada layer pertama dilapis dengan tujuan agar diameter celah saringan sesuai dengan yang diharapkan. Adapun kendalanya yaitu biji hanjeli yang sudah terkupas yang seharusnya turun menuju saringan kedua tertahan pada saringan pertama yang berpengaruh terhadap kapasitas aktual mesin. 


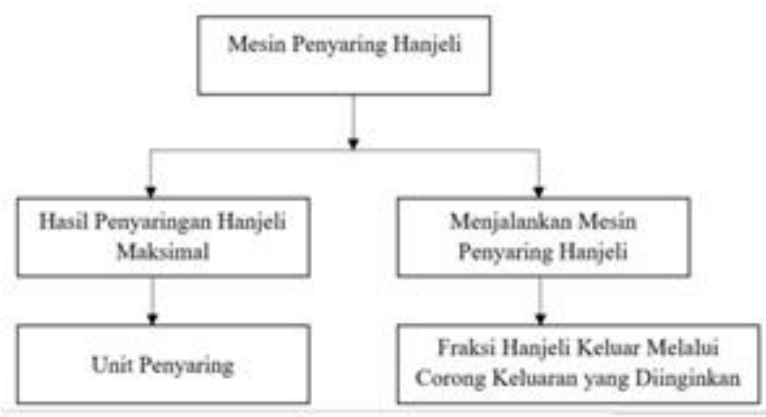

Gambar 2. Skema Rancangan Fungsional

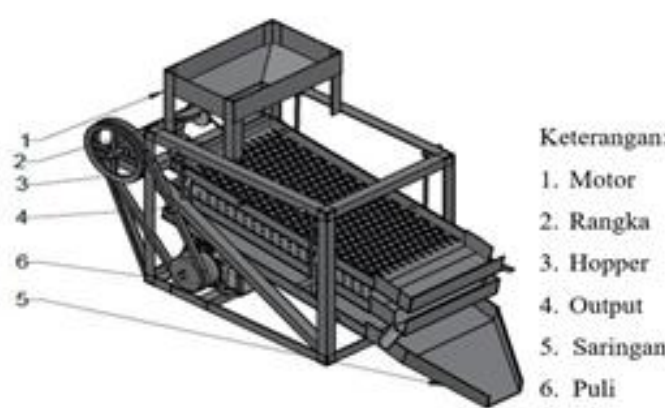

a

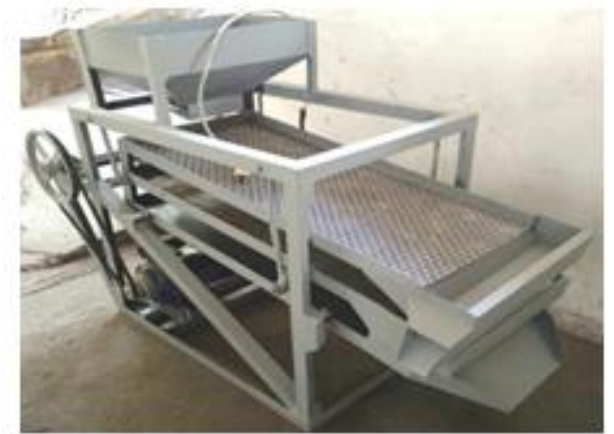

b

Gambar 3. (a) Desain Mesin Penyaring dan (b) Mesin Penyaring Hanjeli

\subsection{Pengujian Mesin}

Pengujian mesin yang dilakukan yaitu uji fungsional dan uji kinerja, parameter ujikinerja yang diamati meliputi: kapasitas aktual, rendemen, efisiensi mesin, energi spesifik pengupasan, kebutuhan daya, kecepatan putar, tingkat kebisingan, dan getaran. Pengujian dilakukan dengan 5 kali pengulangan dimana setiap pengulangan dilakukan dengan menggunakan biji hanjeli sebanyak $2 \mathrm{~kg}$ dengan waktu pemisahan rata-rata selama 4 menit, setelah proses pengujian dilakukan pengukuran massa dari tiga output mesin yang dihasilkan yaitu terdiri dari kulit, biji, dan lapisan epicarp. Pengukuran hasil pemisahan output mesin penyaring hanjeli disajikan pada Tabel 1 .

Berdasarkan kualitas penyaringan hanjeli hasil pengukuran pada Tabel 1 dari hasil pengujian mesin menyatakan bahwa kualitas hasil penyaringan dari mesin masih jauh dari yang diinginkan dilihat dari biji hanjeli yang masih belum terpisahkan karena masih bercampur dengan kulit dan lapisan epicarp (Gambar 4b), namun output yang dihasilkan pada saringan pertama sudah cukup baik karena dilihat dari kualitas yang dihasilkanya itu berupa kulit dan biji hanjeli yang tidak pecah (Gambar 4a). Hal ini dikarenakan pada hasil uji fungsional bahwa mesin hasil pabrikasi masih memiliki kekurangan, yaitu terdapat pada saringan layer pertama dimana tidak berfungsinya saringan dengan baik karena banyak biji hanjeli yang tidak berhasil lolos. Perbandingan hasil mesin penyaring hanjeli disajikan pada Gambar 4. Data hasil pengujian mesin penyaring hanjeli disajikan pada Tabel 2 .

\subsection{Kapasitas Aktual Mesin}

Kapasitas aktual dihitung berdasarkan hasil penyaringan dengan menghitung jumlah bahanyang keluar per satuan waktu. Hasil perhitungan kapasitas aktual mesin penyaring disajikan padaTabel 3.

\subsection{Kebutuhan Daya}

Kebutuhan daya mesin penyaring hanjeli ini yaitu dengan menggunakan motor listrik 0,5 HP sebagai sumber penggerak, untuk mengukur daya pada saat penyaringan yaitu dengan menggunakan alat clamp on meter. Hasil pengukuran kebutuhan daya mesin penyaring disajikan padaTabel 4 . 
Tabel 1. Analisis Hasil Penyaringan

\begin{tabular}{ll}
\hline Deskripsi & Nilai \\
\hline Kulit (Saringan1) & $1,426 \mathrm{~kg}$ \\
Biji (Saringan2) & $0,375 \mathrm{~kg}$ \\
Lapisan epicarp(Saringan3) & $0,085 \mathrm{~kg}$ \\
\hline
\end{tabular}

Tabel 2. Data Hasil Pengujian Mesin Penyaring Hanjeli

\begin{tabular}{lll}
\hline \multicolumn{1}{c}{ Parameter Uji } & Kondisi & \multicolumn{1}{c}{ Nilai } \\
\hline KapasitasAktual & & $29,02 \mathrm{~kg} / \mathrm{jam}$ \\
EfisiensiMesin & & $38,699 \%$ \\
EnergiSpesifik & & $17,368 \mathrm{~kJ} / \mathrm{kg}$ \\
Rendemen & Tanpa Beban & $94,50 \%$ \\
Putaran Motor & DenganBeban & $1448 \mathrm{rpm}$ \\
& TanpaBeban & $1455 \mathrm{rpm}$ \\
KebutuhanDaya & DenganBeban & $0,137 \mathrm{~kW}$ \\
& TanpaBeban & $0,138 \mathrm{~kW}$ \\
PutaranPoros & DenganBeban & $305,07 \mathrm{rpm}$ \\
\multirow{2}{*}{ Kebisingan } & TanpaBeban & $305,66 \mathrm{rpm}$ \\
& DenganBeban & $67,520 \mathrm{~dB}$ \\
Getaran & TanpaBeban & $72,730 \mathrm{~dB}$ \\
& DenganBeban & $2,370 \mathrm{~m} / \mathrm{s}^{2}$ \\
\hline
\end{tabular}

Tabel 3. Hasil Kapasitas Aktual_Mesin

\begin{tabular}{ccccccc}
\hline Deskripsi & \multicolumn{5}{c}{ Ulangan } & Rata-rata \\
\cline { 2 - 6 } & $\mathbf{1}$ & $\mathbf{2}$ & $\mathbf{3}$ & $\mathbf{4}$ & $\mathbf{5}$ & 2 \\
\hline $\begin{array}{c}\text { Kapasitas Aktual } \\
(\mathrm{kg} / \text { jam) }\end{array}$ & 28,16 & 26,25 & 26,78 & 35,60 & 28,30 & 29,02 \\
\hline
\end{tabular}

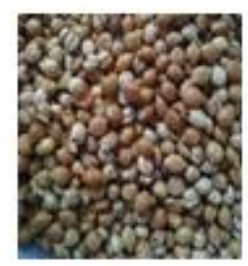

a

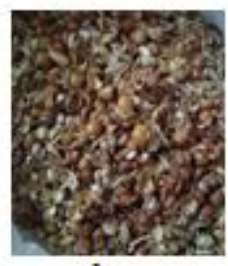

b

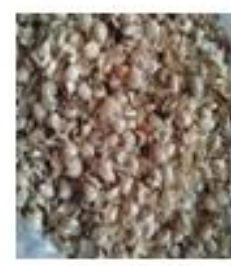

$\mathrm{C}$

Gambar 4. Analisis Hasil Pemisahan Mesin Penyaring (a) Kulit, (b) Biji, dan (c) Lapisan Epicarp

Berdasarkan hasil pengujian kapasitas aktual mesin pada Tabel3, bahwa kapasitas aktual ratarata penyaringan sebesar $29,02 \mathrm{~kg} / \mathrm{jam}$ waktu penyaringan mesin memiliki lama waktu ratarata 4 menit, kapasitas aktual jauh lebih kecil dari kapasitas teoritis mesin dimana kapasitas aktual mesin yang dihasilkan tidak sesuai dengan kriteria perancangan/kapasitas teoritis yang telah ditentukan yaitu sebesar $75 \mathrm{~kg} / \mathrm{jam}$.

\subsection{Efisiensi Mesin}

Efisiensi mesin dapat dihitung berdasarkan perbandingan antara kapasitas aktual dan kapasitas teoritisnya. Kapasitas aktual hasil pengujian rata-rata sebesar $29,02 \mathrm{~kg} / \mathrm{jam}$ sedang kapasitas teoritis sebesar $75 \mathrm{~kg} / \mathrm{jam}$. Dengan demikian efisiensi mesin yaitu 38,70\%. Nilai efisiensi termasuk kecil karen masih jauh dari 100\%. Standar efisiensi mesin sendiri pada umumnya sebesar 80-90\% (Saravacos dkk, 2002). Berdasarkan acuan tersebut maka mesin perlu dilakukan modifikasi agar mencapai efisiensi yang diharapkan.

\subsection{Rendemen Penyaringan}

Rendemen penyaringan dapat dihitung dengan membandingkan massa biji hanjeli bersih yang 
keluar dari saluran pengeluaran (output) dengan massa biji hanjeli yang masuk (input), apabila nilai rendemen penyaringan semakin tinggi, maka proses penyaringan dapat dikatakan baik, karena hanya ada sedikit bahan yang terbuang atau tertinggal. Hasil perhitungan rendemen disajikan pada Tabel 5 .

Berdasarkan hasil pengukuran daya aktual mesin pada Tabel 6, diketahui kebutuhan daya mesin penyaring biji hanjeli pada saat tanpa beban adalah 0,137 kW sedangkan pada kondisi dengan beban membutuhkan daya sebesar $0,138 \mathrm{~kW}$, dari hasil tersebut dapat dilihat bahwa saat ada beban daya menjadi naik dikarenakan adanya daya yang bekerja pada proses pemisahan hanjeli, sehinggapenggunaan motor listrik dengan daya 0,5 HP memenuhi daya yang dibutuhkan untuk menyaring.

\subsection{Energi Spesifik}

Energi spesifik dilakukan untuk mengeteahui besaran energi yang diperlukan untuk memisahkan hanjeli setiap kg. Data hasil perhitungan energi spesifik disajikan pada Tabel 6.

Berdasarkan hasil perhitungan pada Tabel 6 didapatkan energi spesifik rata-rata yang dibutuhkan mesin penyaring sebesar 17,36 kJ/ $\mathrm{kg}$, besarnya nilai energis pesifik penyaringan dipengaruhi oleh kebutuhan daya dan kapasitas aktual mesin tersebut.

\subsection{Tingkat Kebisingan}

Tingkat kebisingan merupakan suara yang tidak dikehendaki dari suatu proses yang dapat menggangu pada kesehatan manusia dan lingkungan, pengukuran tingkat kebisingan dilakukan untuk mengetahui besarnya kebisingan yang ditimbulkan oleh mesin pada saat mesin dioperasikan. Tingkat kebisingan diukur untuk mengetahui nilai ambang batas yang dihasilkan dari suatu mesin yang akan berpengaruh terhadap kinerja operator yang menggunakan mesin tersebut. Hasil pengukuran tingkat kebisingan sebesar 62,78 dB. Berdasarkan standar OSHA 1910,95 (Occupational Safety and Healt Administration) maka tingkat kebisingan mesin penyaring masih dibawah ambang batas yang diijinkan yaitu dibawah $85 \mathrm{~dB}$ sehingga tidak mengganggu untuk operator

\subsection{Getaran Mesin}

Pengukuran getaran pada mesin dilakukan pada saat mesin dioperasikan. Pengukuran getaran menggunakan alat vibration mete. Hasil pengukuran menunjukkan bahwa getaran mesin sebesar $4,88 \mathrm{~m} / \mathrm{s}^{2}$. Berdasarkan nilai ambang batas getaran menurut KEPMENAKER No. KEP 51/Men/1999 getaran yang berlebih

Tabel 4. Hasil Kebutuhan Daya

\begin{tabular}{ccccccc}
\hline \multirow{2}{*}{ Deskripsi } & \multicolumn{9}{c}{ Ulangan } & Rata- \\
\cline { 2 - 6 } & 1 & 2 & 3 & 4 & 5 & rata \\
\hline & \multicolumn{7}{c}{ Tanpa Beban } \\
\hline Kebutuhan daya $(\mathrm{kW})$ & 0,136 & 0,137 & 0,138 & 0,139 & 0,137 & 0,137 \\
\hline \multicolumn{7}{c}{ Dengan Beban } \\
\hline Kebutuhan daya $(\mathrm{kW})$ & 0,140 & 0,137 & 0,138 & 0,137 & 0,137 & 0,138 \\
\hline
\end{tabular}

Tabel 5. Hasil Perhitungan Rendemen Mesin Penyaring Hanjeli

\begin{tabular}{ccccccc}
\hline \multirow{2}{*}{ Deskripsi } & \multicolumn{7}{c}{ Ulangan } & \multirow{2}{*}{ Rata-rata } \\
\cline { 2 - 6 } & $\mathbf{1}$ & $\mathbf{2}$ & $\mathbf{3}$ & $\mathbf{4}$ & $\mathbf{5}$ & \\
\hline Rendemen (\%) & 98,0 & 95,5 & 98,0 & 86,5 & 94,5 & 94,5 \\
\hline
\end{tabular}

Tabel 6. Hasil Pehitungan Energi Spesifik

\begin{tabular}{ccccccc}
\hline \multirow{2}{*}{ Deskripsi } & \multicolumn{7}{c}{ Ulangan } & \multirow{2}{*}{ Rata - rata } \\
\cline { 2 - 6 } & $\mathbf{1}$ & $\mathbf{2}$ & $\mathbf{3}$ & $\mathbf{4}$ & $\mathbf{5}$ & \multirow{2}{*}{ Energi spesifik $(\mathrm{kJ} / \mathrm{kg})$} \\
\hline
\end{tabular}


Tabel 7. Spesifikasi Mesin Penyaring Hanjeli

\begin{tabular}{ll}
\hline \multicolumn{1}{c}{ Nama Komponen } & Spesifikasi \\
\hline Kapasitas Aktual & $29,024 \mathrm{~kg}$ jam \\
\hline Dimensi Keseluruhan & $1034 \mathrm{~mm}$ \\
a.Panjang & $610 \mathrm{~mm}$ \\
b.Lebar & $1000 \mathrm{~mm}$ \\
c. Tinggi & Motor listrik \\
\hline Tenaga Penggerak & $0,5 \mathrm{HP}$ \\
a.Jenis Motor & $1400 \mathrm{rpm}$ \\
b.Daya & \\
c.Kecepatan Putar & Bando V-belt A-55 \\
\hline Sistem Transmisi & Diameter $76,2 \mathrm{~mm}$ \\
a.Sabuk & Diameter $250 \mathrm{~mm}$ \\
b.Puli Motor & Diamete r $=25 \mathrm{~mm}, \mathrm{p}=300 \mathrm{~mm}$ \\
c.Puli Penyaring & \\
d.Poros & Besisiku $40 \times 40 \times 3 \mathrm{~mm}$ \\
\hline Rangka & $800 \mathrm{~mm}$ \\
a.Bahan rangka & $77,5 \mathrm{~mm}$ \\
b.Panjang Rangka & \\
c. Tinggi Rangka &
\end{tabular}

dapat menyebabkan kerusakan pada mesin, secara tidak langsung dapat mengurangi umur teknisnya.

\subsection{Spesifikasi Mesin Penyaring}

Dari hasil pabrikasi mesin penyaring hanjeli sesuai dengan gambar hasil rancangan, akan tetapi ada beberapa komponen yang disesuaikan agar mesin dapat berfungsi dengan baik. Berikut merupakan spesifikasi hasil pabrikasi mesin penyaring yang disajikan pada Tabel 7.

\section{KESIMPULAN DAN SARAN}

\subsection{Kesimpulan}

Mesin penyaring hanjeli telah berhasil dibuat, terdiri dari beberapa komponen utama: rangka, hopper, unit penyaring, sistem transmisi, dan saluran output. Dimensi utama mesin yaitu: panjang $1340 \mathrm{~mm}$, lebar $610 \mathrm{~mm}$, tinggi 1000 mm. Hasil pengujian mesin penyaring hanjeli yaitu: kapasitas aktual mesin yaitu $29,024 \mathrm{~kg} /$ jam, efiesiensi mesin 38,7 \%, kecepatan putaran puli $305 \mathrm{rpm}$, daya motor listrik $0,138 \mathrm{~kW}$, dan tingkat kebisingan 62,78 dB.

\subsection{Saran}

Perlu modifikasi pada unit penyaring, sebaiknya saringan diganti dengan lubang saringan yang sesuai, sehingga kapasitas mesin dapat meningkat untuk memenuhi kriteria perancangan yaitu sebesar $75 \mathrm{~kg} / \mathrm{jam}$ dan perlu ditambahkan blower untuk memisahkan dedak hanjeli.

\section{DAFTAR PUSTAKA}

Badan Pusat Statistik. 2016. Statistik Indonesia. Jakarta.

Duke,J.A.1983.Coixlacryma-jobiL.Hand Book of Energy Crops. Terdapat pada http:// www.hort.purdue.edu/newcro p/ dukeenergy/Coix_lacryma- jobi.html. (Diakses pada tanggal 2 Desember 2017).

Keputusan Menteri Tenaga Kerja. 1999. Nilai Ambang Batas Faktor Fisika di Tempat Kerja. No.51: Jakarta

Nurmala, T. dan Irwan, A.W.2007.Pangan Alternatif Berbasis Serealia Minor. Bandung. Penerbit: Pustaka Giratuna.

Nurmala,T.,Warid, A. Q., dan Tjutju S.A. 2009. Eksplorasi, Identifikasi dan Analisis Keragaman Plasma Nuftah Tanaman Hanjeli (Coix lacryma-Jobi L.) Sebagai Sumber Bahan Pangan Berlemak di Jawa Barat. 
Saravacos, G., Maroulis, Z. 2002. Handbook of Food Processing Equipment. New York: Marcel Dekker, Inc.

Taufan, M. 2014. Modifikasi Mesin Pengupas Hanjeli TEP 0112 (MPH-TEP 0112). Skripsi. Jurusan Teknik Pertanian,
Fakultas Teknologi Industri Pertanian, Universitas Padjadjaran, Jatinangor

Yulianto Fiky, dkk. 2006. Pengembangan Plasma Nuftah Hanjeli (Coix lacrymajobi) Sebagai Pangan Potensial Berbasis Tepung di Pluncut Kabupaten Bandung. PKM. Universitas Padjajaran 